\title{
POSITIVE BLOOD CULTURED ISOLATED BACTERIA IN CHILDREN UNDER 90 DAYS OLD ADMITTED FOR FEVER IN A PEDIATRIC CHILEAN HOSPITAL, BETWEEN 2014 AND 2016
}

Cecilia Piñera MD ${ }^{1}, 2$, Monserrat Valdés ${ }^{1}$, Giancarla Gambi ${ }^{1}$, Belen González² ${ }^{1}$ Facultad de Medicina Universidad de Chile, ${ }^{2}$ Hospital Exequiel González Cortés

\section{Background}

Fever in infants younger than 3 months: Can reflect Serious Bacterial Infection SBI) versus viral infection $\rightarrow$ routine Blood cultures $(\mathrm{BC})$

- Time of observation for occult bacteremia not well establish

\section{Objective}

To describe type and positivity time of isolated bacteria in $\mathrm{BC}$ in infants under 3 months admitted for fever.

\section{Methods}

- Retrospective descriptive study at a Children's Hospital in Chile

- Positive BC taken between 2014-2016 in young infants admitted for fever

- Excluded: infants not hospitalized, without fever and with comorbidity.

- Identification and time of positivity of each bacteria, clinical, labaratory and demographic data were recorded.

- Demographic variables and the clinical outcome was obtained.

\section{Results}

There were 172 young infants with positive BC. Only 51 patients met inclusion criteria. 21 pathogenic microorganisms were identified and 30 were considered contamination, mainly $S$. coagulase negative. The median time of positivity was $10 \mathrm{hrs}$. After 24 hours of culture, bacterial growth was detected in 48 samples $(94 \%)$, the remaining 3 corresponded to bacteria considered to be contamination.

\begin{tabular}{|c|c|c|c|c|}
\hline Bacteria & $\mathbf{N}^{\circ}$ & $\%$ & $\begin{array}{c}\text { Median } \\
\text { (hrs) }\end{array}$ & $\begin{array}{l}\text { Max } \\
\text { Time } \\
\text { (hrs) }\end{array}$ \\
\hline Total & 51 & 100 & 10 & 96 \\
\hline S. coag negative* & 23 & 45 & 10 & 75 \\
\hline E. coli & 10 & 20 & 6,7 & 19,2 \\
\hline Micrococcus $\mathrm{sp}^{*}$ & 5 & 9 & 16,3 & 96 \\
\hline S. agalactiae & 3 & 6 & 5 & 6,2 \\
\hline S. pyogenes & 3 & 6 & 10 & 13,6 \\
\hline Pantoea sp & 1 & 2 & 2 & 2 \\
\hline E. faecalis & 1 & 2 & 3,9 & 3,9 \\
\hline Salmonella group D & 1 & 2 & 9,1 & 9,1 \\
\hline S. aureus & 1 & 2 & 15 & 15 \\
\hline \begin{tabular}{|c|} 
Serratia \\
marcescens
\end{tabular} & 1 & 2 & 19,9 & 19,9 \\
\hline H. influenzae spp & 1 & 2 & 21,1 & 21,1 \\
\hline Bacillus $\mathrm{sp}^{*}$ & 1 & 2 & 60 & 60 \\
\hline
\end{tabular}

Table 2. Bacterial, fever duration and inflammatory parameters

\begin{tabular}{|l|c|c|c|}
\hline Bacteria & $\begin{array}{c}\text { Fever } \\
\text { (hrs) }\end{array}$ & $\begin{array}{c}\text { CRP } \\
(\mathbf{m g} / \mathbf{L})\end{array}$ & $\begin{array}{c}\text { Leukocytes } \\
\left(\mathbf{c e l} / \mathbf{m m}^{\mathbf{3}}\right)\end{array}$ \\
\hline Total & $\mathbf{2 4 , 9}$ & $\mathbf{4 9 , 8}$ & $\mathbf{1 2 . 7 1 8}$ \\
\hline E. coli & 37,4 & 104,9 & 17.120 \\
\hline S. agalactiae & 8,6 & 52,9 & 13.800 \\
\hline S. pyogenes & 17,3 & 60,9 & 14.666 \\
\hline $\begin{array}{c}\text { Salmonella } \\
\text { group D }\end{array}$ & 12 & 1,3 & 11.000 \\
\hline $\begin{array}{l}\text { H. Influenzae } \\
\text { spp }\end{array}$ & 72 & 67 & 16.700 \\
\hline S. aureus & 12 & 57 & 13.800 \\
\hline E. faecalis & 24 & 9,1 & 6.000 \\
\hline Pantoea sp & 12 & 63 & 10.300 \\
\hline $\begin{array}{c}\text { Contaminant } \\
\text { bacteria* }\end{array}$ & 28,9 & 32,5 & 11.073 \\
\hline
\end{tabular}

Table 3. Isolated Bacteria and distribution according to diagnoses

\begin{tabular}{|lcccccc|}
\hline \multicolumn{1}{|c}{ Bacteria } & $\mathrm{N}^{\circ}$ & UTI & $\begin{array}{c}\text { Occult } \\
\text { Bacteremia }\end{array}$ & Sepsis & Celulitis & Pneumonia \\
\hline Total & 20 & 9 & 4 & 2 & 2 & 2 \\
E. coli & 10 & 9 & 1 & & & \\
S. agalactiae & 3 & & 1 & 2 & 2 & \\
S. pyogenes & 3 & & 1 & & & 1 \\
Salmonella group D & 1 & 1 & & & \\
H. Influenzae spp & 1 & & 1 & & \\
S. aureus & 1 & 1 & & & 1 \\
E. faecalis & 1 & & & & & \\
Pantoea sp & 1 & & & & & \\
\hline
\end{tabular}

\section{Conclusions}

- Isolated pathogenic bacteria in young infants admitted for fever correspond mainly to gramnegative bacilli and streptococci.

- All the isolated pathogens were detected before 24 hours of incubation.

- In our serie we observed a high porcentage of contaminant bacteria $(12 \%$ of total $B C)$, for wich we must review the sampling process.

- There is not yet enough available evidence regarding the recommended observation time for febrile infants without a source, but with the current automated bacterial growth detection systems it seems that $24 \mathrm{hrs}$ is an adequate period to rule out hidden bacteremia. 